antagonists / A.W. Thomas, M. Kavaliers, F.S. Prato [et al.] // Peptides. - 1997. - Vol. 18. - P. 703-709.

18. Prato F.S. Extremely low frequency magnetic fields can either increase or decrease analgaesia in the land snail depending on field and light conditions / F.S. Prato, M. Kavaliers, A.W. Thomas // Bioelectromagnetics. - 2000. - Vol. 21. - P. 287-301.

19. Del Seppia C. Exposure to a hypogeomagnetic field or to oscillating magnetic fields similarly reduce stress-induced analgesia in C57 male mice / C. Del
Seppia, P. Luschi, S. Ghione [et al.] // Life Sci. - 2000. - Vol. 66, Is.14. - P. 1299-1306.

20. Choleris E. Shielding, but not zeroing of the ambient magnetic field reduces stress-induced analgesia in mice / E. Choleris, Seppia Del, A.W. Thomas [et al.] // Proceedings. Biological sciences. The Royal Society. - 2002. - Vol. 269. - P. 193-201.

21. Prato F.S. Daily repeated magnetic field shielding induces analgesia in CD-1 mice / F.S. Prato, J.A. Robertson, D. Desjardins [et al.] // Bioelectromagnetics. - 2005. - Vol. 26. - P. 109-117.

\title{
FEATURES OF PROCESSES OF REPRODUCTION OF POPULATIONS OF RODENTS IN THE CONDITIONS OF SOUTHERN ARAL SEA AREA
}

\author{
Shaniyazov Userbay Bukharbaevich \\ Karakalpak Center of prophylaxis \\ of quarantine and extrahazardous infections \\ of Ministry of health of \\ Republic of Uzbekistan \\ Mambetullaeva Svetlana Mirzamuratovna \\ Doctor of biology science, professor, \\ Karakalpak scientific research \\ Institute of nature of science \\ DOI: $\underline{10.31618 / E S U .2413-9335.2019 .2 .64 .220}$
}

\section{ANNOTATION}

To the article the results of researches of processes of reproduction of populations of two types of rodents are driven in the conditions of Southern Aral Sea Area. Comparative analysis of population structure midday and large chick-weeds, showed some distinctions in character of ecological specialization of kinds that reflect the features of strategy of their population mechanisms of adaptation substantially. Both types of rodents prevail in the association of shallow mammals of the inspected territory.

Keywords: Southern Aral Sea Area, reproduction, population structure, mechanisms of adaptation.

The study of dynamics of population structure in space and in time is considered one of major tasks of modern ecology. As the most general scientific issue having and the primary applied value, determination of potential "ecological reserve" of populations of different types of shallow mammals is examined in the changing terms of habitat.

Small mammals, being the important component of natural ecosystems, are widely used as model objects in ecological researches, including those that affect the problems of anthropogenic transformations of environment. It is a numerous group of animals, that, by virtue of the position in the trophic chains of ecosystems, directly perceives pressure of one or another negative factors of environment on large territories and can be used for the indication of violation of environment.

In ecological researches principle of comparison of adaptation features of shallow mammals with different ecological specialization to the changing terms of environment is used widely enough [2, p. 200; 7, p. 332-344 and other]. A problem of study of population ecological mechanisms of adaptation of rodents to the terms of the anthropogenic pressing is most actual presently.

Studies were undertaken an on territory of Northwestern Kyzylkum (sublimity of Beltau, Janadarya, Akchadarya, Central Kyzylkum, Nukus sands), on Usturt and on the areas of oasis of lower Amudarya for period 2002-2018 years.
Rhombomus optimus is the deserted eurytopic kind, widely widespread in sands of Central Asia. This kind, being the basic base-line on a quantity rodent of the deserted zones, behaves to the number of animals having a large negative value in a national economy.

Reproduction of large chick-weed was studied by many researchers $[1$, c. $52-54 ; 5$, c. $125 ; 3$, c. $28-29 ; 6$, c. 491]. However in modern ecological terms question about intensity of reproduction, amount of broods and number of babies in the dung of chick-weeds requires more fresh information. The analysis of the collected materials shows that at the Kyzylkum population of large chick-weed in March-September months among the spending winter females of chick-weed caught by us the single did not meet, all he were pregnant or feeding.

It is set that the young females of the first brood of current year of birth usually participate in reproduction and bring one dung only. A size of dung is 3-4 babies. The young females of the second dung proceed to reproduction only next year. Depending on the state of abiotic factors (fallouts, temperature etc.) and forage factors the percent of propagative females hesitates on years and seasons. Among entrapped, the percent of propagative females made $40-45 \%$ in spring, in summer $20-25$, by the autumn of $10-18 \%$. The amount of embryos hesitates from 2 to 10 .

Meriones meridianus is widely widespread in ridge sands copsy полукустарниками. Quantity her relatively high in мелкобугристых alluvial sands on 
periphery of oasis, and in uneven sands, on sandy ridges and on the takyr plains of the clay desert quantity her not high (5-6\% hits, or on the average on 1 ha $3-4$ youngs of wild animal).

\section{DIAGNOSTIC VALUE OF THE DETERMINATION OF THE LEVEL OF CONDUCTIVE CYTOKINES IN CERVICAL INTRAEPITELIAL NEOPLASIA}

\section{SUMMARY}

Kalandarova Amina Nurullaevna

Candidate of medicine science,

Aripova Tamara Uktamovna

Academician, Doctor of medicine science Institute of Human Immunology and

Genomics Academy of Sciences of the Republic of Uzbekistan

The results of a comprehensive survey of 111 women of reproductive age with varying degrees of CIN residing in the Republic of Karakalpakstan were studied. The following research methods were used: clinical, ultrasound, endoscopic (colposcopy), cytological, immunological, bacterioscopic, bacteriological, PCR. It was revealed that the severity of immunological disorders is correlated with the nature of pathological changes in cervical intraepithelial tissue, which indicates the involvement of the immune system in the pathogenesis of CIN.

Key words: cervical intraepithelial neoplasia, immunity, immunocorrection.

By diseases of the cervix, prior invasive cervical cancer or precancerous cervical disease include epithelial dysplasia I-III severity [cervical intraepithelial neoplasia (Cervical Intraepithelial Neoplasia - CIN) or squamous intraepithelial lesions (Squamous Intraepithelial Lesion - SIL)]. Cervical intraepithelial neoplasias are characterized by impaired differentiation of epithelial cells as a result of proliferation of cambial elements with the development of their atypia, loss of polarity and impaired histostructure [6,7].

It is promising to study the characteristics of local production of cytokines in PVI associated with neoplastic changes in the cervical epithelium, which is necessary to assess the immune response and predict the risk of malignant transformation of infected cells $[2,4]$. The development of an immune response to a tumor antigen is not always a guarantee of the mobilization of antitumor protection, since it can lead to the induction of those immunological mechanisms that stimulate tumor growth. Despite the active study of the role of cytokines in the implementation of antitumor immunity, as well as their applicability in the diagnosis and treatment of tumors of different localization, the characteristics of cytokine metabolism and the dynamics of production of growth factors in patients with dysplasia and neoplasia of the cervical epithelium at the cervical level are not well understood.

Material and research methods

We presented data from our research on a comprehensive survey of 111 women of reproductive age with varying degrees of CIN living in the Republic of Karakalpakstan. Of the women surveyed, CIN I was detected in 45 , who made up the 1 st group, CIN II - in 35 women - the 2nd group and 31 women with CIN III - the 3rd group.

Immunological studies were conducted by studying some parameters of the cellular (CD3, CD4, CD8, CD16, CD20, CD25, CD95) humoral (IgG, IgA, IgM) and cytokine (IL-1b, IL-6, TNF $\alpha$ and IFN $\gamma$ ) status. The control group consisted of 24 healthy women.
We used the following research methods: clinical, ultrasound, endoscopic (colposcopy), cytological, immunological, bacterioscopic, bacteriological, PCR. Molecular biological studies with DNA typing and PCR were considered important and informative evidence of the presence of infectious pathogens. For the purpose of early diagnosis of cervical dysplasia, a study of smears from the surface of the cervical epithelium and cervical canal was performed.

Immunological research methods. Evaluation of the immune status of modern concepts implies a comprehensive study of the immune system, including testing its most important functional units. The determination of cellular immunity. Evaluation of the state of the immune system is carried out by expression of $\mathrm{CD}$ differentiation antigens. We identified the following markers of immunocompetent cells (ICC): $\mathrm{CD} 3+-, \mathrm{CD} 4+-, \mathrm{CD} 8+-, \mathrm{CD} 20+-, \mathrm{CD} 16+-$ lymphocytes. Determination of humoral immunity. The determination of the serum concentration of immunoglobulins of the main three classes A, M and G is carried out by the generally accepted method of radial immunodiffusion according to Mancini (1963).

Determination of cytokine status. The concentrations of cytokines IL-2, IL-6, TNF $\alpha$ and IFN $\gamma$ were determined in serum by the method of solid phase ELISA in accordance with the manufacturer's recommendations (Vector Best, Novosibirsk, Russian Federation).

\section{Results and discussion}

Analysis of the data showed that HPV was detected in $77.8 \%$ of the women surveyed. Of these, HPV risk of high oncogenic risk $(16,18,31,33)$ was detected in $28.6 \%$ of patients with CIN I, in $86.2 \%$ of patients with CIN II, in 88.6-88\% of patients with CIN III and cervical cancer. Analysis of the data for the presence of TORCH infection showed a fairly high detectability of HSV (85.9\%) and CMV (87.8\%) infections, urea- (25.6\%) - and mycoplasma (14.7\%), Chlamydia trachomatis $(42,3 \%)$, Mycoplasma genitalium (42.3\%). Mixed infection was observed in $36.8 \%$ of the women surveyed. This suggests a certain 